\title{
The Use of Hoop Nets Seeded with Mature Brook Trout to Capture Conspecifics
}

\author{
JAMES A. LAMANSKy, JR.* ${ }^{1}$ AND ERnEST R. KeELEY \\ Department of Biological Sciences, Stop 8007, Idaho State University, 921 South Eighth Avenue, \\ Pocatello, Idaho 83209, USA \\ Michael K. Young \\ Rocky Mountain Research Station, Forestry Sciences Laboratory, 800 East Beckwith Avenue, \\ Missoula, Montana 59801, USA
}

\author{
Kevin A. Meyer
}

Idaho Department of Fish and Game, Nampa Research, 1414 East Locust Lane, Nampa, Idaho 83686, USA

\begin{abstract}
The brook trout Salvelinus fontinalis, a native of eastern North America, is considered an invasive species in the western United States because it has been implicated in the decline of many native trout species there. Current methods for controlling brook trout are usually time-consuming and expensive and are sometimes harmful to nontarget species. We tested a passive method of control using hoop nets to capture fish during brook trout spawning in the fall. We seeded nets with four different combinations of brook trout (a single male, three males, a male-female pair, and a single female) as well as with no fish to determine whether hoop-net capture success was greater in nets seeded with conspecifics. Nets with a male-female pair captured $30 \%$ more brook trout than the next best treatment; the differences were significant, however, only in comparison with the catches resulting from the single- and multiple-male treatments. We also found that hoop nets captured five times as many mature male brook trout as mature females. Although we were unable to conclusively identify a treatment that increases hoop-net capture rates, hoop nets were successful in removing up to $34 \%$ of the estimated number of brook trout in the study stream, even though we did not attempt to maximize capture efficiencies. Hence, hoop netting may be helpful in reducing brook trout numbers if alternative methods of removal are undesirable.
\end{abstract}

The brook trout Salvelinus fontinalis, a species native to eastern North America, is now widely distributed across the western United States (Behnke 1992). They have been reported to be present in $50 \%$ of the interior Columbia River basin watersheds (Thurow et al. 1997) and 25-50\% of streams sampled in western Wyoming and southeastern Idaho (Kruse et al. 2000; Meyer et al. 2006a). Brook trout are also implicated in the decline of many native trout populations throughout the region (Dunham et al. 2002; Peterson and Fausch 2003; Fausch et al. 2006). Consequently, fisheries managers often consider controlling brook trout populations as an essential part of conserving native trout populations.

Two popular methods used by fisheries managers to control undesirable fish populations in streams are electrofishing and chemical toxicants. Although both

\footnotetext{
* Corresponding author: tlamansky@idfg.idaho.gov

${ }^{1}$ Present address: Idaho Department of Fish and Game, Nampa Research, 1414 East Locust Lane, Nampa, Idaho 83686, USA.
}

Received December 10, 2007; accepted July 7, 2008 Published online February 16, 2009 methods are widely used and relatively successful, they also have shortcomings (Finlayson et al. 2005). Chemical toxicants may kill nontarget aquatic organisms (Finlayson et al. 2000), which often makes their use to control fish populations politically controversial (Finlayson et al. 2005). Consequently, the use of chemicals may be precluded where sensitive nontarget species are present or their application is socially unacceptable. Permitting requirements and other administrative details must also be addressed and add to the complications of using chemicals (Bettoli and Maceina 1996; Finlayson et al. 2005). The greatest downside to electrofishing is that capture efficiency is reduced in deep pools, complex habitats, and areas with heavy cover and is biased toward larger fish (Reynolds 1996; Thompson and Rahel 1996). As a result, complete removal is difficult (Meyer et al. 2006b), may require several passes per year for two or more years, and may only be feasible in small, relatively simple habitats (Kulp and Moore 2000; Shepard and Nelson 2004). Therefore, the development of other techniques to remove fish that alleviate many of these concerns is important.

A more recently considered technique for removing nonnative fishes is to use nets seeded with mature 
conspecifics to exploit potential pheromonal attraction and thereby increase capture rates (Sorensen and Stacey 2004; Johnson et al. 2006; Wagner et al. 2006). Many fish species, including salmonids, are known to secrete chemicals that elicit a particular response in conspecifics (Newcombe and Hartman 1973; Rouger and Liley 1993; Cardwell et al. 1996). In most studies of fish, the compound or blend of compounds that act as the pheromone are unknown and the mechanisms for the synthesis and reception of the pheromone are not well understood (Johansen 1985; Sherwood et al. 1991; Siefkes et al. 2003). Most experiments have only confirmed that a chemical produced from one individual elicits a specific response from another of the same species (Liley and Stacey 1983).

Although using pheromonal attraction to selectively remove fish has promise, there are few investigations of its potential to control populations of brook trout. In a laboratory study, Sveinsson and Hara (1995) observed that adult Arctic char Salvelinus alpinus were attracted to water in which a spermiating male was held. In an analogous, short-term field experiment, Young et al. (2003) found that captures of adult brook trout in hoop nets seeded with mature males were greater than those in nets seeded with mature females or those that lacked a seed fish. Our objective was to replicate this experiment in an Idaho stream containing large numbers of brook trout but to (1) conduct it throughout the spawning period, (2) examine additional combinations of mature brook trout as attractants, and (3) estimate the percentage of brook trout removed by hoop nets and thereby to evaluate the efficacy of such nets in controlling brook trout populations.

\section{Study Area}

We conducted the study in East Threemile Creek, a small tributary in the Beaver Creek drainage in northeastern Idaho approximately $6 \mathrm{~km}$ east of the town of Spencer (Universal Transverse Mercator coordinates 412797E 4916090N, zone 12, NAD27). East Threemile Creek is one of the "Sinks" drainages of Idaho that typically disappear into the surface material of the Snake River plain approximately 50-60 $\mathrm{km}$ before reaching the Snake River. The study stream averaged $1.7 \mathrm{~m}$ wide (range, $0.9-2.3 \mathrm{~m}$ ) and $0.07 \mathrm{~m}$ deep $(0.01-0.47 \mathrm{~m})$ and included the upper $6.2 \mathrm{~km}$ of stream above a two-way weir installed to stop the emigration of brook trout from a large series of beaver ponds below the section. East Threemile Creek drains from north to south, with an average gradient of $3.5 \%$. The substrate is composed mainly of gravel and cobble, and the riparian zone is dominated by willows Salix spp. The elevation of the study section ranges from
$1,944 \mathrm{~m}$ at the weir to $2,323 \mathrm{~m}$ at the upper extent. Brook trout are the only fish species present and they inhabit the entire stream section from the weir to the uppermost source of water.

\section{Methods}

Abundance estimates.-We sampled the study stream on 3-5 August 2004 at 12 sites by conducting multiple-pass removals using backpack electrofishers (Smith-Root model 15-D; settings: $1 \mathrm{~ms}, 60 \mathrm{~Hz}, 400 \mathrm{~V}$ DC). We calculated brook trout abundance and the associated 95\% confidence intervals (CIs) using a maximum-likelihood estimator (MicroFish 3.0; Van Deventer and Platts 1989). Because electrofishing generates unequal capture efficiencies for different size-classes of fish (Reynolds 1996), we calculated separate abundance estimates for fish $100 \mathrm{~mm}$ total length (TL) or larger and fish less than $100 \mathrm{~mm}$ TL. We regard these as minimum estimates of brook trout abundance because of the negative bias in removal estimates (Rosenberger and Dunham 2005). Our initial sample site was chosen randomly in the first $750 \mathrm{~m}$ upstream from the weir, and the remaining sites were chosen systematically every $500 \mathrm{~m}$ upstream of the first site. The electrofishing sites were $43-75 \mathrm{~m}$ long and enclosed with block nets to meet the assumption of a closed population. After fish were captured, we measured total length $(\mathrm{mm})$ and mass $(\mathrm{g})$. All fish were released in the general area of capture. The stream was stratified into an upper and lower section to make abundance estimates because of obvious differences in the density of brook trout between the two sections. In each stratum, abundance was estimated by calculating the linear density of trout (trout $/ \mathrm{m}$ ) in each sample section, averaging the density across all sections, and then multiplying the average density by the length of the stream. Confidence intervals $( \pm 95 \%)$ were calculated by taking the square root of the sum of variances from all sample sections and multiplying by 1.96 . We calculated streamwide abundance by summing the estimates from both strata.

Study design and statistical analyses.-We used five different treatments to test the efficacy of using mature brook trout as attractants in hoop nets: (1) a single mature male, (2) three mature males, (3) a mature male-female pair, (4) a single mature female, and (5) no fish. We chose these combinations to facilitate comparisons with those used in the study by Young et al. (2003), namely, a single male, a single female, and no fish. We included the male-female pair and three male treatments to test the possibility that fish of different sexes or multiple fish would express or increase an attraction effect and increase the number of 
fish captured in hoop nets, as suggested by Young et al. (2003).

We deployed the nets in the stream in a randomized block design to account for the variability in spatial factors that could confound treatment effects, such as localized changes in stream size or fish abundance. We used 80 nets divided into eight blocks. The first block was randomly placed in the first $750 \mathrm{~m}$ upstream from the weir, and subsequent blocks were located upstream at 750-m intervals. The five treatments were grouped together as a set, two sets representing a block. The two sets within each block were installed continuously, the nets being installed $10 \mathrm{~m}$ apart on average (range, 4-50 $\mathrm{m})$, with the exact distance dependant on the availability of suitable habitats. Treatments were randomly assigned to nets within a set. The experimental unit was the individual net, and the response variable was the sum of the number of fish captured over the entire trapping period. We analyzed the data using a three-way analysis of variance (ANOVA) to test for differences in mean captures by treatment. The factors used in the model were net treatment, block, set within block, and the treatment $\times$ block interaction. All factors were considered fixed effects. We also analyzed the differences in the number of captures by sex by comparing the mean differences (males less females); differences were considered significant if their $95 \%$ CIs did not include zero. All capture data were transformed using the function $\log _{e}(x+1)$ to equalize the variances across treatments. Analyses were conducted for all mature fish and for mature males, mature females, and immature fish separately by comparing the leastsquares means between treatments after controlling for other variables $(\alpha=0.05)$. Pairwise comparisons for treatments were tested by means of Tukey's honestly significant difference (HSD) test. All statistical analyses were conducted using the general linear model procedure in SAS computer software (version 9.1; SAS Institute 2005).

We collected mature brook trout to use in net treatments by electrofishing below the weir. The sex of treatment fish was identified by examining morphological differences and light massage of the gonads. Eggs from mature females could be felt through the body wall of the abdomen or they were expressed from the oviduct when slight pressure was applied to the belly of the fish. Similarly, mature males expressed milt when pressure was applied to the abdomen (Strange 1996). Fish were then placed in perforated polyvinyl chloride tubes $(460 \mathrm{~mm}$ long, $101 \mathrm{~mm}$ in diameter) enclosed on both ends with soft, 12-mmmesh netting. Tubes containing fish were then placed in the cod end of hoop nets. The hoop nets were constructed using four $38-\mathrm{cm}$-diameter fiberglass hoops covered in delta heavy 44, 6.3-mm nylon mesh; the nets were $1.8 \mathrm{~m}$ long with a single throat (5.0-7.0 $\mathrm{cm}$ ) and had 61-cm leads (panels that extended out from the mouth to help guide fish). When fish captured in nets were used as treatment fish, we recorded the net, treatment, and date that the fish was captured to allocate it to the appropriate capture net during analysis. Because of concerns about stress possibly changing the attractive nature of the seed fish, we intended to replace treatment fish every $3 \mathrm{~d}$. This was not always feasible because of the lack of captured fish of the correct sex or state of maturity; thus, treatment fish were changed on average every $7 \mathrm{~d}$ (SD, 5).

We conducted the hoop net removal experiment during the brook trout spawning season (SeptemberOctober). We installed hoop nets on 15 September 2004, placed treatments in the nets the next day, and removed all nets on 20 October 2004. Hoop nets were placed in the stream in habitat units long enough to contain a net and deep enough to submerge the throat $(0.10-0.15 \mathrm{~m})$. We anchored the nets with metal stakes after orienting them with their mouths facing downstream; we then tied the leads so that they would not block the entire stream (Figure 1). All nets were checked once daily during the 35-d sampling period. All captured brook trout were removed from the traps as they were checked, killed with a blow to the head, and frozen on dry ice within an hour of capture. In the laboratory, fish were thawed, measured, and sexed. Males were considered mature if gonads were large and milky white and immature if small and threadlike. Females were considered mature when ovaries contained large, well-developed eggs and immature if ovaries were thin and granular with no developed eggs.

\section{Results}

\section{Abundance Estimates}

After electrofishing the 12 sites on East Threemile Creek, we estimated the total 2004 abundance of brook trout $100 \mathrm{~mm}$ or longer as 2,020 ( $\pm 410,95 \% \mathrm{CI})$ and that of fish less than $100 \mathrm{~mm}$ as $1,950( \pm 697,95 \%$ CI). We encountered more fish in the lower regions of stream. Of this minimal estimate of 3,970 brook trout, $1,360(34 \%)$ were captured in hoop nets $(777 \geq 100$ $\mathrm{mm}, 583<100 \mathrm{~mm})$. We captured 658 sexually mature brook trout (544 males, 114 females). All of the males and about one-half of the females $100 \mathrm{~mm}$ or larger were sexually mature. Therefore, we captured $54 \%$ of the estimated number of mature males and $23 \%$ of the mature females, assuming a 50:50 sex ratio in the population (McFadden 1961; Cooper et al. 1962). 

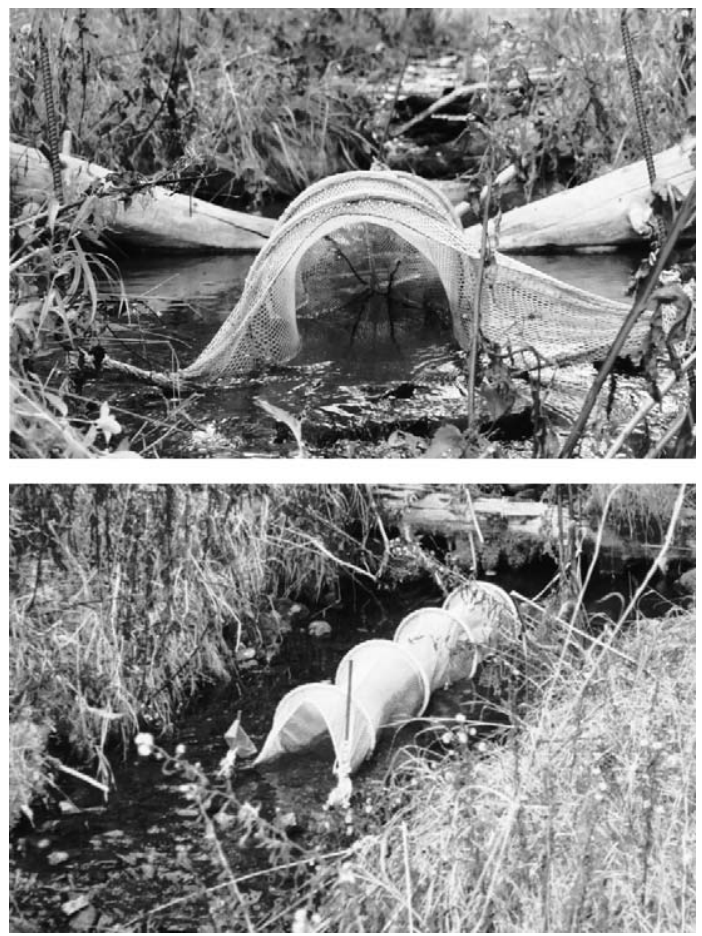

FIGURE 1.-Photographs of a typical hoop net placed in East Threemile Creek in 2004 and seeded with conspecifics to attract and capture brook trout for population control purposes. The top photograph is looking upstream into the mouth of the net and the throat to the cod end. The lower photograph shows a hoop net anchored in the stream channel. The mouth of the net is facing downstream.

\section{Capture Rates of Brook Trout}

Although certain treatments appeared to capture more brook trout (Table 1), we detected mixed differences among the treatments. Nets seeded with the male-female pair caught $30 \%$ more mature brook trout (235) than nets with no fish (166) and $73 \%$ more fish than nets with the single male (64). We captured 702 immature brook trout, but the numbers captured by treatment and block were more evenly distributed among the treatments than the numbers for mature fish (Table 2).

The ANOVA model for the total number of mature brook trout captured indicated that the block and net treatment factors accounted for a significant proportion of the variation in capture rates. The block effect accounted for $15 \%$ of the variation in capture rates $\left(F_{7}\right.$ $\left.{ }_{31}=4.10, P=0.003\right)$, whereas the net treatment effect accounted for $12 \%$ of the total variation $\left(F_{4,31}=4.38\right.$, $P=0.006$; Figure 2A). However, we could not detect any differences between treatment means using Tukey's HSD pairwise tests (all $P$-values $>0.05$ ). The set effect accounted for $12 \%$ of the variation in the model but did not significantly influence capture rates $\left(F_{8,31}=1.34, P=0.26\right)$.

The captures of males, females, and juveniles varied in response to the main effects of the model. When the capture of males was analyzed separately from that of females, ANOVA indicated that the number of mature males captured was influenced by the block $\left(F_{7,31}=\right.$ 4.05, $P=0.003)$ and treatment: $\left(F_{4,31}=4.59, P=\right.$ $0.005)$ but not the set $\left(F_{1,31}=1.87, P=0.17\right)$. The blocking factor accounted for $24 \%$ of the variation in the model for males and the net treatment factor for $16 \%$. A posteriori HSD tests between treatments for mature males indicated that the male-female pair and single-female treatments captured significantly more fish than the single-male treatment, but no other comparisons between treatments were significantly different for males (Table 3). The only factor influencing the number of mature females captured was the block $\left(F_{7,31}=3.74, P=0.005\right)$, not the set $\left(F_{8}\right.$, $\left.{ }_{31}=1.25, P=0.31\right)$ or net $\left(F_{4,31}=1.15, P=0.35\right)$, and it accounted for $24 \%$ of the variation in the model. Significantly more males were captured in all treatments when comparing the difference between the number of males and females captured (i.e., none of the confidence intervals for the differences between males and females included zero; Figure 3).

The ANOVA model for immature brook trout captured in hoop nets indicated that blocks accounted for a significant proportion of the variability in capture

TABLE 1.-The number of mature brook trout captured (male : female ratios in parentheses) in hoop nets seeded with five different fish treatments in eight blocks (stream sections) in East Threemile Creek from 16 September to 20 October 2004.

\begin{tabular}{lccccccccc}
\hline & \multicolumn{7}{c}{ Block } & & \\
\cline { 2 - 7 } \multicolumn{1}{c}{ Treatment } & 1 & 2 & 3 & 4 & 5 & 6 & 7 & 8 & Total \\
\hline Male-female pair & $37(26: 11)$ & $29(23: 6)$ & $65(49: 16)$ & $7(7: 0)$ & $71(69: 2)$ & $13(12: 1)$ & $9(9: 0)$ & $4(3: 1)$ & $235(198: 37)$ \\
No fish & $23(22: 1)$ & $19(19: 0)$ & $47(23: 24)$ & $42(34: 8)$ & $10(10: 0)$ & $3(2: 1)$ & $10(7: 3)$ & $12(11: 1)$ & $166(128: 38)$ \\
Three males & $31(15: 16)$ & $13(10: 3)$ & $2(2: 0)$ & $31(30: 1)$ & $3(3: 0)$ & $2(2: 0)$ & $14(13: 1)$ & $1(1: 0)$ & $97(76: 21)$ \\
One male & $16(9: 7)$ & $1(1: 0)$ & $16(13: 3)$ & $6(5: 1)$ & $5(5: 0)$ & $9(9: 0)$ & $11(10: 1)$ & 0 & $64(52: 12)$ \\
One female & $\mathrm{a}$ & $13(13: 0)$ & $27(25: 2)$ & $23(22: 1)$ & $15(15: 0)$ & $10(8: 2)$ & $6(5: 1)$ & $2(2: 0)$ & $96(90: 6)$ \\
Total & $107(72: 35)$ & $75(66: 9)$ & $157(112: 45)$ & $109(98: 11)$ & $104(102: 2)$ & $37(33: 4)$ & $50(44: 6)$ & $19(17: 2)$ & $658(544: 114)$ \\
& & & & & & & & &
\end{tabular}

${ }^{\mathrm{a}}$ Not tested. 
TABLE 2.-Number of immature brook trout captured in hoop nets seeded with five different fish treatments in eight blocks (stream sections) in East Threemile Creek from 16 September to 20 October 2004.

\begin{tabular}{lrrrrrrrrr}
\hline & \multicolumn{7}{c}{ Block } & \\
\cline { 2 - 7 } \multicolumn{1}{c}{ Treatment } & 1 & 2 & 3 & 4 & 5 & 6 & 7 & 8 & Total \\
\hline Male-female pair & 21 & 15 & 41 & 7 & 2 & 3 & 1 & 1 & 91 \\
No fish & 51 & 137 & 4 & 10 & 2 & 1 & 0 & 0 & 205 \\
Three males & 34 & 36 & 46 & 14 & 10 & 10 & 6 & 1 & 157 \\
One male & 10 & 68 & 30 & 15 & 8 & 6 & 3 & 0 & 130 \\
One female & $\mathrm{a}$ & 36 & 12 & 32 & 8 & 5 & 14 & 2 & 119 \\
Total & 116 & 292 & 133 & 78 & 30 & 25 & 24 & 4 & 702 \\
\hline
\end{tabular}

${ }^{\mathrm{a}}$ Not tested.

rates, but net treatment (Figure 2B) and set had no effect. The blocking effect explained $42 \%$ of the variation in the model $\left(F_{7,31}=6.46, P<0.0001\right)$, whereas the net treatment only explained $8 \%\left(F_{4,31}=1.99, P=0.12\right)$ and set explained $2 \%\left(F_{1,31}=0.9, P=0.12\right)$.

\section{Discussion}

Identifying whether the sex and number of mature brook trout used as attractants in hoop nets increased
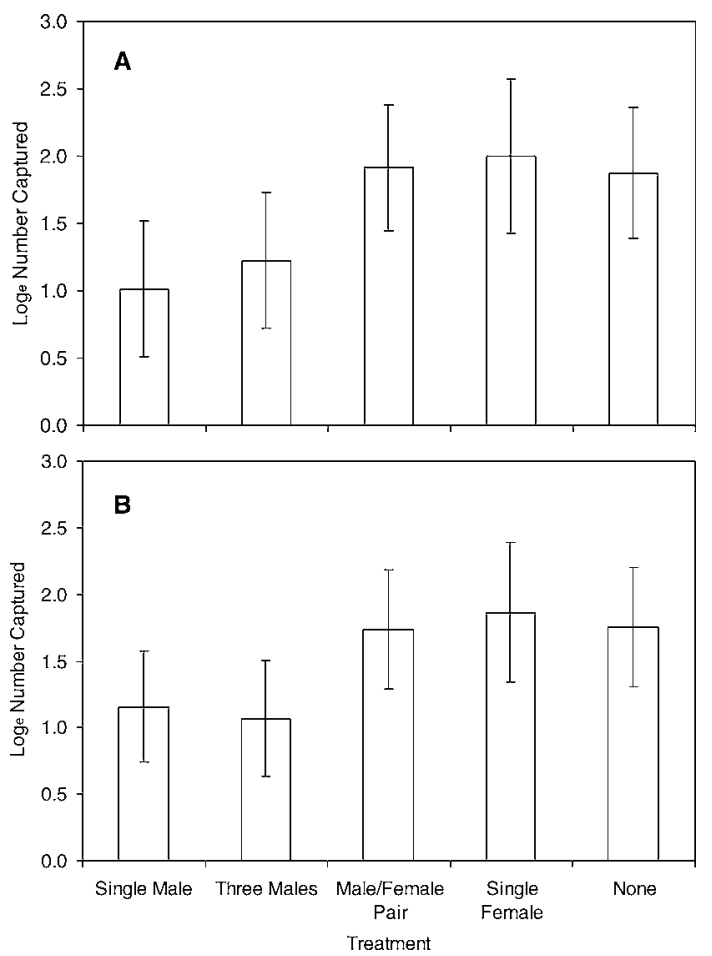

Figure 2.-Mean $\log _{e}$ transformed numbers of (A) mature and (B) immature brook trout captured in hoop nets seeded with five different treatments during the 2004 spawning season (16 September to 20 October) in East Threemile Creek. The barred vertical lines indicate the $95 \%$ confidence intervals. the number of brook trout captured was the main objective of this study. We found that nets seeded with a male-female pair captured the most mature fish, nearly four times as many as were captured in the least effective treatment, a single male. In contrast, Young et al. (2003) captured significantly more mature brook trout in nets seeded with males, but also used fewer treatment types and did not operate nets through the entire brook trout spawning period. Because they did not use a male-female pair treatment or operate nets throughout the spawning period, capture rates may have been affected if (1) attraction was increased by having both sexes together or (2) the responsiveness of brook trout changed as the spawning season progressed. In Atlantic salmon Salmo salar, for example, Moore and Scott (1991) observed that olfactory sensitivity to testosterone effectively ceased in precocious males $14 \mathrm{~d}$ before females ovulated. If such mechanisms are important in pheromonal attraction among brook trout, Young et al. (2003) potentially missed a period where attractiveness shifted among sexes.

TABLE 3.-Tukey's honestly significant difference comparisons of differences between the mean numbers of mature male brook trout captured in hoop nets seeded with five different treatments in East Threemile Creek from 16 September to 20 October 2004. Differences with $95 \%$ confidence limits that do not include zero are statistically significant and are marked with asterisks $(\mathrm{P}<0.05)$.

\begin{tabular}{llcc}
\hline & & \multicolumn{2}{c}{$95 \%$ Confidence limits } \\
\cline { 3 - 4 } \multicolumn{1}{c}{ Treatment comparison } & Difference & Lower & Upper \\
\hline Pair versus 1 female & 0.053 & -0.842 & 0.948 \\
Pair versus no fish & 0.193 & -0.636 & 1.021 \\
Pair versus 3 males & 0.769 & -0.047 & 1.586 \\
Pair versus 1 male & $0.918^{*}$ & 0.123 & 1.713 \\
One female versus no fish & 0.140 & -0.755 & 1.035 \\
One female versus 3 males & 0.716 & -0.167 & 1.600 \\
One female versus 1 male & $0.865^{*}$ & 0.001 & 1.729 \\
No fish versus 3 males & 0.577 & -0.240 & 1.393 \\
No fish versus 1 male & 0.725 & -0.070 & 1.520 \\
Three males versus 1 male & 0.149 & -0.634 & 0.931 \\
\hline
\end{tabular}




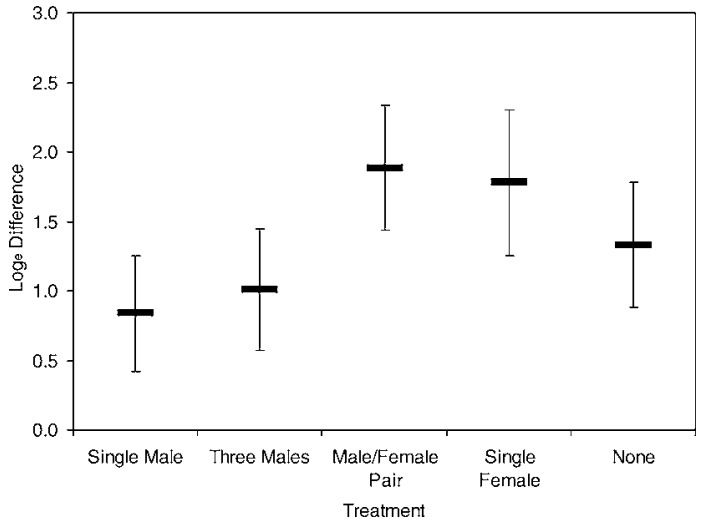

FIGURE 3.- Mean $\log _{e}$ transformed differences in the numbers of male and female brook trout captured in hoop nets seeded with five different treatments during the 2004 spawning season (16 September to 20 October) in East Threemile Creek. Differences are significant where the $95 \%$ confidence intervals (barred vertical lines) do not include zero.

We captured more mature males than females because male brook trout probably move more frequently in search of mates. Although evidence suggests that males move more often than females (Anderson and Quinn 2007), the mechanism causing movement is unclear. The release of a pheromonal attractant is a possible explanation as a basis for male movement in brook trout; however, the effect of treatment in our study was small, as evidenced by the amount of variation explained in the model (12\%). This suggests that pheromonal attraction is only one factor in locating mates, and perhaps other cues are more important when males and females are in close proximity. Alternatively, we may have been unable to detect an attractive effect because at least 2,000 additional brook trout were in the stream, making any attractant ubiquitous. Regardless, brook trout are known to move considerably (Adams et al. 2000; Peterson and Fausch 2003), and the movement of males may increase population fitness by reducing mate competition among male kin, thereby decreasing the chance of reproducing with related females (Hutchings and Gerber 2002). Searching behavior by males could decrease the likelihood of breeding with relatives because natal site fidelity has been noted to be stronger in spawning females in some salmonids (Neville et al. 2006). Therefore, we probably captured more male brook trout simply because they encountered nets more frequently while moving around looking for mates.

The blocking factor in this experiment explained more of the variation ( $24 \%$ for both males and females) in the model than the treatment factor. Blocking was included in the design to account for uncontrollable variation due to stream width, elevation, temperature, and gradient. However, the largest uncontrolled variable was the number of brook trout present in the different sections of stream. Considerably more brook trout were found in the lower sections of stream during the period when the population estimates were made because suitable habitat was more extensive (i.e., there was a higher frequency of pools and undercut banks) than in the upstream sections, which had a higher gradient and larger substrates (J. A. Lamansky Jr., unpublished data); this is consistent with the gradient of decreasing captures in blocks from downstream to upstream (Tables 1, 2).

We removed up to $34 \%$ of the total estimated population (up to $54 \%$ of mature males and $23 \%$ of mature females) of the brook trout in East Threemile Creek despite the fact that we designed the experiment to examine the effects of treatments on capture, not to maximize removal. However, because our electrofishing abundance estimates are known to be negatively biased (Riley and Fausch 1992; Peterson et al. 2004), the proportion removed should be considered a maximum. Based on a mark-recapture estimate during their 8-d study, Young et al. (2003) captured 23\% of the adult brook trout in a $1.6-\mathrm{km}$ study reach. The levels of removal in both of these studies are low compared with chemical and electrofishing methods designed to completely eradicate brook trout (Gresswell 1991; Kulp and Moore 2000). Further experiments are necessary to evaluate the maximum level of removals attainable using hoop nets to capture brook trout and whether different netting strategies would lead to reductions in brook trout abundance sufficient to warrant the use of this approach.

The development of a passive method such as hoop netting to remove undesired fish species is important in light of issues with current methods of control, primarily chemical treatment and electrofishing (Finlayson et al. 2005). Oftentimes, sensitive species are present, diminishing the suitability of using chemicals or electrofishing because of potential harm to those species (Nielsen 1998). Avoiding the use of chemicals or electrofishing would be especially important if small populations of sensitive species remain in areas with large numbers of undesired fish. Although questions remain about the maximum effectiveness and likelihood of total removal using hoop nets, we found that their use can remove a substantial proportion of a brook trout population.

\section{Acknowledgments}

We express gratitude to the crews who assisted with the field work for this project, including Joe Kozfkay, 
John Cassinelli, Andy Knight, Mike Vaughn, Matt Grover, Dane Oldham, Art Butts, Dan Garren, Trapper Bradshaw, Daniel Ball, Alice Cook, Matt Wilberding, Ron Roberts, Sylvia Copeland, Dan Henbest, Steve Seiler, and Colleen and Salma Lamansky. We also thank Sarah Nelson and Steve Elle for assistance with laboratory work. Helpful comments were provided by Colden Baxter, Ken Rodnick, Ann Gironella, Matt Culp, and an anonymous reviewer. This project was conducted with support from Idaho State University and the Idaho Department of Fish and Game and was funded by the Bonneville Power Administration.

\section{References}

Adams, S. B., C. A. Frissell, and B. E. Rieman. 2000. Movements of nonnative brook trout in relation to stream channel slope. Transactions of the American Fisheries Society 129:623-638.

Anderson, J. H., and T. P. Quinn. 2007. Movements of adult coho salmon (Oncorhynchus kisutch) during colonization of newly accessible habitat. Canadian Journal of Fisheries and Aquatic Sciences 64:1143-1154.

Behnke, R. J. 1992. Native trout of western North America. American Fisheries Society, Monograph 6, Bethesda, Maryland.

Bettoli, P. W., and M. J. Maceina. 1996. Sampling with toxicants. Pages 303-333 in B. R. Murphy and D. W. Willis, editors. Fisheries techniques, 2nd edition. American Fisheries Society, Bethesda, Maryland.

Cardwell, J. R., P. W. Sorensen, G. J. Van Der Kraak, and N. R. Liley. 1996. Effect of dominance status on sex hormone levels in laboratory and wild-spawning male trout. General and Comparative Endocrinology 101:333341.

Cooper, E. J., J. A. Boccardy, and J. K. Anderson. 1962. Growth rate at different population densities in a small infertile stream. Progressive Fish-Culturist 24:74-80.

Dunham, J. B., S. B. Adams, R. E. Schroeter, and D. C. Novinger. 2002. Alien invasions of aquatic ecosystems: toward an understanding of brook trout invasions and potential impacts on inland cutthroat trout in western North America. Reviews in Fish Biology and Fisheries 12:373-391.

Fausch, K. D., B. E. Rieman, M. K. Young, and J. B. Dunham. 2006. Strategies for conserving native salmonid populations at risk from nonnative fish invasions: tradeoffs in using barriers to upstream movement. U.S. Forest Service General Technical Report RMRS-GTR-174.

Finlayson, B. J., R. A. Schnick, R. L. Cailteux, L. DeMong, W. D. Horton, W. McClay, C. W. Thompson, and G. J. Tichacek. 2000. Rotenone use in fisheries management: administrative and technical guidelines manual. American Fisheries Society, Bethesda, Maryland.

Finlayson, B., W. Somer, D. Duffield, D. Propst, C. Mellison, T. Pettengill, H. Sexauer, T. Nesler, S. Gurtin, J. Elliot, F. Partridge, and D. Skaar. 2005. Native inland trout restoration on national forests in the western United States: time for improvement? Fisheries 30(5):10-19.

Gresswell, R. E. 1991. Use of antimycin for removal of brook trout from a tributary of Yellowstone Lake. North American Journal of Fisheries Management 11:83-90.

Hutchings, J. A., and L. Gerber. 2002. Sex-biased dispersal in a salmonid fish. Proceedings of the Royal Society of London B 269:2487-2493.

Johansen, P. H. 1985. Female pheromone and the behaviour of male guppies (Poecilia reticulata) in a temperature gradient. Canadian Journal of Zoology 63:1211-1213.

Johnson, N. S., M. A. Luehring, M. J. Siefkes, and W. Li. 2006. Mating pheromone reception and induced behavior in ovulating female sea lampreys. North American Journal of Fisheries Management 26:88-96.

Kruse, C. G., W. A. Hubert, and F. J. Rahel. 2000. Status of Yellowstone cutthroat trout in Wyoming waters. North American Journal of Fisheries Management 20:693-705.

Kulp, M. A., and S. E. Moore. 2000. Multiple electrofishing removals as a management tool for restoration of southern Appalachian brook trout, Great Smoky Mountains National Park. North American Journal of Fisheries Management 20:940-946.

Liley, N. R., and N. E. Stacey. 1983. Hormones, pheromones, and reproductive behaviour in fish. Pages 1-63 in W. S. Hoar, D. J. Randall, and E. M. Donaldson, editors. Fish physiology, volume 9B. Academic Press, New York.

McFadden, J. T. 1961. A population study of the brook trout, Salvelinus fontinalis. Wildlife Monographs 7.

Meyer, K. A., D. J. Schill, J. A. Lamansky, Jr., M. R. Campbell, and C. C. Kozfkay. 2006a. Status of Yellowstone cutthroat trout in Idaho. Transactions of the American Fisheries Society 135:1329-1347.

Meyer, K. A., J. A. Lamansky, Jr., and D. J. Schill. 2006b. An unsuccessful brook trout electrofishing removal project in a small Rocky Mountain stream. North American Journal of Fisheries Management 26:849-860.

Moore, A., and A. P. Scott. 1991. Testosterone is a potent odorant in precocious male Atlantic salmon (Salmo salar L.) parr. Philosophical Transactions of the Royal Society of London B 332:241-244.

Newcombe, C., and G. Hartman. 1973. Some chemical signals in the spawning behavior of rainbow trout (Salmo gairdneri). Journal of the Fisheries Research Board of Canada 30:995-997.

Neville, H. M., D. J. Isaak, J. B. Dunham, R. F. Thurow, and B. E. Rieman. 2006. Fine-scale homing and localized movement as shaped by sex and spawning habitat in Chinook salmon: insights from special autocorrelation analysis of individual phenotypes. Molecular Ecology 15:4589-4602.

Nielsen, J. L. 1998. Scientific sampling effects: electrofishing California's endangered fish populations. Fisheries 23(12):6-12.

Peterson, D. P., and K. D. Fausch. 2003. Upstream movement by nonnative brook trout (Salvelinus fontinalis) promotes invasion of native cutthroat trout (Oncorhynchus clarki) habitat. Canadian Journal of Fisheries and Aquatic Sciences 60:1502-1516.

Peterson, J. T., R. F. Thurow, and J. W. Guzevich. 2004. An evaluation of multiple-pass electrofishing for estimating the abundance of stream-dwelling salmonids. Transactions of the American Fisheries Society 133:462-475.

Reynolds, J. B. 1996. Electrofishing. Pages 221-253 in B. R. Murphy and D. W. Willis, editors. Fisheries techniques, 
2nd edition. American Fisheries Society, Bethesda, Maryland.

Riley, S. C., and K. D. Fausch. 1992. Underestimation of trout abundance size by maximum likelihood removal estimates in small streams. North American Journal of Fisheries Management 12:768-776.

Rosenberger, A. E., and J. B. Dunham. 2005. Validation of abundance estimates from mark-recapture and removal techniques for rainbow trout captured by electrofishing in small streams. North American Journal of Fisheries Management 25:1395-1410.

Rouger, Y., and N. R. Liley. 1993. Effect of social environment on plasma hormones and availability of milt in spawning male rainbow trout (Oncorhynchus mykiss Walbaum). Canadian Journal of Zoology 71:280 285.

SAS Institute. 2005. SAS version 9.1. SAS Institute, Cary, North Carolina.

Shepard, B. B., and L. Nelson. 2004. Conservation of westslope cutthroat trout by removal of brook trout using electrofishing: 2001-2003. Report to Montana Fish, Wildlife and Parks, Helena.

Siefkes, M. J., A. P. Scott, B. Zelinski, S. Yun, and W. Li. 2003. Male sea lampreys, Petromyzon marinus L., excrete a sex pheromone from gill epithelia. Biology of Reproduction 69:125-132.

Sherwood, N. M., A. L. Kyle, H. Kreiberg, C. M. Warby, T. H. Magnus, J. Carolsfeld, and W. S. Price. 1991. Partial characterization of a spawning pheromone in the herring Clupea harengus pallasi. Canadian Journal of Zoology 69:91-103.

Sorensen, P. W., and N. E. Stacey. 2004. Brief review of fish pheromones and discussion of their possible uses in the control of nonindigenous teleost fishes. New Zealand Journal of Marine and Freshwater Research 38:399-417.

Strange, R. J. 1996. Field examination of fishes. Pages 433446 in B. R. Murphy and D. W. Willis, editors. Fisheries techniques, 2nd edition. American Fisheries Society, Bethesda, Maryland.

Sveinsson, T., and T. J. Hara. 1995. Mature males of Arctic charr, Salvelinus alpinus, release F-type prostaglandins to attract conspecific mature females and stimulate their spawning behaviour. Environmental Biology of Fishes 42:253-266.

Thompson, P. D., and F. J. Rahel. 1996. Evaluation of depletion-removal electrofishing of brook trout in small Rocky Mountain streams. North American Journal of Fisheries Management 16:332-339.

Thurow, R. F., D. C. Lee, and B. E. Rieman. 1997. Distribution and status of seven native salmonids in the interior Columbia River basin and portions of the Klamath River and Great Basins. North American Journal of Fisheries Management 17:1094-1110.

Van Deventer, J., and W. Platts. 1989. A computer software system for entering, managing, and analyzing fish capture data from streams. U.S. Forest Service Research Note INT-352.

Wagner, C. M., M. L. Jones, M. B. Twohey, and P. W. Sorensen. 2006. A field test verifies that pheromones can be useful for sea lamprey (Petromyzon marinus) control in the Great Lakes. Canadian Journal of Fisheries and Aquatic Sciences 63:475-479.

Young, M. K., B. K. Micek, and M. Rathburn. 2003. Probable pheromonal attraction of sexually mature brook trout to mature male conspecifics. North American Journal of Fisheries Management 23:276-282. 